\title{
DREAMS, EMBODIED IMAGINATION AND THE CREATIVE MIND: A PILOT STUDY
}

\author{
Richard R. SZUSTER * \\ University of Hawaii at Manoa, John A. Burns School of Medicine, Department of Psychiatry \\ 4211 Waialae Ave, Suite 207 Honolulu, HI 96816, United States
}

Received 01 June 2018; accepted 04 September 2018

\begin{abstract}
This pilot study is the first attempt to investigate the use of embodied imagination in the creative process. Embodied imagination is an emerging method for working with dreams and the imagination that employs two fundamental processes: First, embodied imagination takes place in a hybrid state of awareness including both wake-like and dream-like experience. Second, embodied imagination focuses on direct engagement with dream images. Seven participants, currently engaged in a creative project, were guided in a two-step embodied imagination process. The first session focused on a memory of feeling blocked in the creative process and the second session focused on a dream that had emerged between sessions. This process was found to be an effective support for the creative process. During the second session an electroencephalograph was employed to determine whether participants entered into an awakened mind state during the embodied imagination process. Awakened mind is hypothesized to be a more creative form of waking awareness characterized by a specific relative amplitude relationship between brain wave frequencies. During the embodied imagination session participants were found to enter awakened mind and were able to re-enter awakened mind after the session when re-engaging the "composite", a somatically anchored network of experiences generated during the embodied imagination session.
\end{abstract}

Keywords: awakened mind, creativity, dreams, embodied imagination.

\section{Introduction}

Novelty and utility, the new and the useful - these are the defining elements of the creative process (CP) (Runco \& Jaeger, 2012); a process thought to involve two distinct but complimentary modes of engagement. The first mode relies on a conscious, analytical, and rational approach that is logical, linear and incrementally builds over time (Kounios \& Beeman, 2015). The second mode is non-linear, non-rational, and relies on inspiration suddenly emerging into consciousness, after a period of "unconscious incubation" (Kounios \& Beeman, 2009, 2015). Related to unconscious influences, there are many accounts of dreams impacting conscious awareness and facilitating the CP (Barrett, 1993, 2001; Bulkeley, 2010; Schredl \& Erlacher, 2007; Castle, 1994; White \& Taytroe, 2003). Embodied imagination (EI)

*Corresponding author. E-mail: szus.md@gmail.com 
is an emerging method of working with dreams that has been employed in the CP (Bosnak, Busetto, \& Wolfe, 2015; Sonenberg, 2003), but the current study represents a first attempt to systematically investigate its efficacy in this area.

\section{The creative process}

Graham Wallas (1926) proposed a four stage model of the CP that is still influential amongst creativity researchers (Sadler-Smith, 2015). Consistent with John Kounios and Mark Beeman (2015), Graham Wallas' four stages oscillate between conscious and unconscious modes of cognition and experience: In the preparation stage conscious efforts are utilized to acquire and apply knowledge to the project. In the incubation stage conscious attention is diverted away and unconscious processes ensue. In the illumination stage creative ideas spontaneously emerge into consciousness and lastly, in the verification stage, conscious efforts are re-engaged to evaluate the products of the illumination stage.

It is relatively easy to understand the preparation and verification stages of Wallas' model as they are familiar modes of conscious experience. In contrast, the incubation and illumination stages are more obscure and, as non-rational processes, are more elusive to rational understanding. Nonetheless, the notion of a period of incubation, prior to creative emergence, has significant empirical support (Sio \& Ormerod, 2009); and while different theoretical paradigms have been proposed (Smith \& Dodds, 1999), unconscious influences seem to be of central importance to this stage (Gilhooly, 2016; Ritter, Baaren, Dijksterhuis, 2012; Ritter \& Dijksterhuis, 2014).

At a neurophysiological level, Kounios and Beeman $(2009,2015)$ have identified electroencephalographic (EEG) and anatomical features that distinguish the conscious and unconscious modes in the CP. Unconscious activity in the incubation stage is theorized to include spreading cortical activation that allows for divergence of thought and the formation of non-obvious associations. Theoretically, this is a process whereby disorganized information becomes more and more organized until it reaches an equilibrium and is transferred to conscious awareness (Ritter \& Dijksterhuis, 2014). At the moment of insight, when the transfer of information to conscious awareness occurs, increased right temporal gamma brain wave activity has been identified (Jung-Beeman et al., 2004).

\section{Embodied imagination}

EI is an approach to working with dreams, memories and the imagination developed by Robert Bosnak, a Jungian psychoanalyst. EI builds upon the foundational developments of Carl Jung's analytical psychology (1974), James Hillman's archetypal psychology (2004) and Henry Corbin's expanded apprehension of the imagination (1964). While supported by these historical foundations, EI offers a unique approach, both conceptually and in practice.

In the $\mathrm{CP}$, the goal of $\mathrm{EI}$ is to move beyond habitual conscious waking experience into an augmented awareness that includes unconscious phenomenon and supports creative emergence. In pursuit of this goal, EI employs two fundamental processes: First, EI takes place in a 
hybrid state of awareness that simultaneously has elements of both waking consciousness and dreaming. Second, EI engages dream images in a manner that invites a direct participation in the independent intelligence of the images themselves. The details of the EI process used in this study are provided in the methods section, while the theoretical foundations are elaborated below.

Bosnak describes the state of awareness evoked in the EI process as an intensified version of the hypnogogic state (the transitional state between wake and sleep naturally experienced at sleep onset):

"Through careful attention to details of the image environment, affective states, and physical sensations, the natural waking hypnogogic state can be artificially intensified, so the initially flimsy image ambience becomes increasingly dense, sometimes perceived as equally real, as while dreaming. At the same time waking consciousness is strengthened" (2007, pp. 38-39).

Hence, a dream-like state and a wake-like state are concurrently intensified into a dual consciousness state that is maintained throughout the EI process. In this state, access to waking functions such as memory and external perceptivity are maintained while simultaneously experiencing an environmental ambience typical of a dream state.

Along with the establishment of this dual consciousness state, EI engages dream images in a manner that acknowledges them as possessing an independent functionality and intelligence. The theoretical foundation for this approach relies upon Corbin's extensive study of visionary experience (1964). Bosnak describes his perspective on dream images in the following manner:

\footnotetext{
"What are these substantive images that embody their own active intelligence? They aren't figments, nor are they reconstructed memories, day residues, even though they sometime dress themselves in the events of the day. They are not sub-personalities, as I have already said. According to the visionaries studied by Henry Corbin, they are forms of intelligence which present themselves as substantive bodies to the perceiving eye of the creative imagination" (2007, p. 11).
}

Conceptualizing dream images in this way is a significant departure from conventional understanding. Following Corbin (1964), it posits the imagination as an organ of perception, capable of apprehending an imaginal world populated by substantive images.

In summary, the EI process first facilitates a "dual-consciousness" state of awareness that results in the simultaneous presence of wake-like experience and dream-like experience. Second, attention is paid to engaging and directly experiencing the active intelligence of dream images. The experiences are then worked into a relational network termed a "composite" (described in the methods section below). The net result is the creation of a dynamic interactional effect between the contents of waking consciousness and the contents of the dream state. These interactions are initiated within the EI session and are then re-enlivened repeatedly between sessions. The combination of these interactional effects is theorized to support a creative state of mind that is fundamental to the use of EI in the CP. Further, the state of mind evoked in the EI process suggests similarities to what has been described as an “awakened mind” (“AM”). 


\section{Creative mind - awakened mind}

The "AM" is a term used by the English bio-physicist and psychologist C. Maxwell Cade to describe a neurophysiological state which he identified in creative people across different disciplines (Cade \& Coxhead, 1979). Cade's AM state includes a subjective sense of feeling more lucid, fluid and creative. Unique to Cade's approach was his focus on collecting EEG recordings of his subjects. Using a two channel EEG that he labelled the Mind Mirror (MM), Cade identified a specific EEG signature (detailed in the methods section) that he associated with the AM state.

Relevant to an understanding of Cade's EEG based AM theories is an understanding of EEG frequencies, as they relate to states of awareness and arousal during the normal sleepwake cycle. Brain waves become progressively lower in frequency and higher in amplitude as brain activation is reduced in the transition from wake to sleep. As these changes in frequency occur, different phenomenal features become manifest (Kokoszka \& Wallace, 2011). Cade's AM state focuses on four commonly identified brain wave frequency bands (PaceSchott, Hobson, \& Stickgold, 2008):

1) Beta waves $(14-30 \mathrm{~Hz})$, are prominent in the waking state and attenuate as sleep ensues;

2) Alpha waves $(8-13 \mathrm{~Hz})$, emerge as arousal decreases in eyes closed relaxed states, and as drowsiness ensues at sleep onset;

3) Theta waves $(4-7 \mathrm{~Hz}$ ), become prominent during sleep onset when waking awareness further wanes and sleep begins to deepen. Theta waves are associated with the perception of dream-like imagery. This association is most clear in the hypnogogic state, as consciousness transitions between wake and sleep (Mavromatis, 2010). However, the association is also present in rapid eye movement sleep (Nir \& Tononi, 2010; Nishida, Pearsall, Buckner, \& Walker, 2009; Nishida et al., 2007; Takahara, Kanayama, Nittono, \& Hori, 2006), an activated, mixed brain wave state frequently associated with dreaming;

4) Delta waves (1-3 Hz), are present in deep sleep while wake-like awareness is generally absent.

In the ordinary waking state beta waves predominate along with reduced relative amplitudes of alpha, theta and delta waves (Pace-Schott, 2009). In contrast, AM is a state in which there are increased relative amplitudes of the alpha, theta and delta waves concurrent with beta waves. Hence AM can be considered an integrative state of consciousness, wherein conscious experience typical of waking is present concurrent with the typically unconscious experience of sleep and dreams. While this is a novel approach to understanding the neurophysiological basis of states of consciousness it has parallels in recent studies focusing on functional and anatomical relationships between brain networks. For instance, one current focus of neuroscientific inquiry relevant to EI, AM, dreams and creativity, is on the relationship between the brain's task negative, default mode network (DMN), and the task positive, executive control network (ECN). The DMN is a network of mid-line and inferior parietal brain sites active when the brain is engaged in internal mentation (Andrews-Hanna, 2012; Buckner, Andrews-Hanna, \& Schacter, 2008; Raichle et al., 2001). The DMN has also been 
proposed to be a neural correlate of dreaming during sleep (Domhoff \& Fox, 2015), and of daydreaming/imagining during wake (Fox, Nijeboer, Solomonova, Domhoff, \& Christoff, 2013). In contrast, the ECN, which includes the dorsolateral pre-frontal cortex as a core hub, is engaged during tasks requiring externally directed attention and supports executive functions, cognitive control and conscious decision making (Vincent, Kahn, Snyder, Raichle, \& Buckner, 2008). The DMN and ECN have been considered to have an anti-correlated relationship, as engagement with one network tends to suppress activity in the other (Fox et al., 2005). However, in studies of creativity there is emerging evidence of coordinated activity between the DMN and ECN (Beaty et al., 2014; Ellamil, Dobson, Beeman, \& Christoff, 2012; Mok, 2014). That is, the networks involved with alert, attentive waking (ECN) and dream and imagination (DMN) function in an interactive fashion in the CP. Also, in studies of meditation; open monitoring-type meditation has been selectively shown to enhance creativity (Bass, Nevicka, \& Velden Ten, 2014), and similarly involves interaction between DMN sites and ECN sites (Marzetti et al., 2014). While the methodologies used in these studies differ, they are compatible with Cade's AM model, all suggesting that creativity can be increased by facilitating access to dream-like consciousness by waking consciousness.

\section{Study purpose}

Anecdotal reports suggest that EI is an effective support for the CP (Bosnak, Busetto, \& Wolfe, 2015; Sonenberg, 2003). While the phenomenology of the EI process has been described (Bosnak, 2007), the neurophysiological features present during the EI process have not been examined. AM is a state of mind theorized to be associated with an increased capacity for creativity (Cade \& Coxhead, 1979). Fundamental to EI and AM is an experience of waking consciousness being present concurrent with experiences typical of dreaming and sleep. As such, the EEG profile of the state evoked in the EI process would theoretically be expected to have similarities to the AM state. Informed by these possibilities, this pilot study focuses on two basic questions: a) Does EI enhance the CP as judged by the self-reports of study participants?; b) Does EI evoke an EEG pattern consistent with the AM pattern?

\section{Method}

\subsection{Participants}

Seven participants (see Table 1) were recruited by word of mouth in the author's community. Inclusion was based upon the participant being currently involved in a creative project and experiencing a sense of the project being stalled or blocked. In keeping with the naturalistic design of the study, an intentional effort was made to recruit participants from a range of fields and to define the CP broadly to include the arts, sciences, technology and personal problem solving. A preliminary meeting was held with each participant to explain the purpose of the study, methods, benefits, risks, and to establish consent to participate. During this meeting, information was gathered regarding the status of the participant's current creative project. 
Table 1. Participant descriptions (source: created by author)

\begin{tabular}{|c|c|c|l|l|}
\hline Participant & Gender & Age (years) & \multicolumn{1}{c|}{ Occupation } & \multicolumn{1}{c|}{ Creative endeavor } \\
\hline 1 & Female & 48 & Social worker/Poet & Poetry writing \\
\hline 2 & Male & 54 & Engineering professor & Engineering textbook \\
\hline 3 & Male & 25 & Musician/Composer & Music composition \\
\hline 4 & Female & 70 & Psychologist & Autobiography \\
\hline 5 & Female & 42 & Philosophy professor & Philosophy book \\
\hline 6 & Male & 64 & Organizational specialist & Major life transition \\
\hline 7 & Male & 52 & Graphic designer & Mobile device app \\
\hline
\end{tabular}

\subsection{Procedure}

All of the procedural aspects of the study were conducted by the author. Engagement with a memory of the creative project being stalled or blocked was the starting point for the EI process. The theoretical underpinning of this method was the notion that engagement with the "block" would facilitate the emergence of a responsive dream, which would be helpful in re-establishing creative progress with the project. In the following, each step is described in detail.

\subsubsection{Session 1 - induction}

The participant was first settled into a state of relaxed presence by focusing on breathing and body awareness. The participant was then invited to imaginally return to a moment when they were engaged with their project, and felt blocked. Once a felt bodily sense of re-experiencing the block was established the emotional and somatic components were amplified, by directing intensified attention to these experiences. The somatic counterpart of the experience of being blocked was somatically "anchored" by intensifying the attentional focus on the region of the body where the experience was most palpable. Once this somatic anchor was established, the participant was next invited to focus on the anchored experience and imagine it as a new environment, an environment that could be entered and explored via imagination. Participants were encouraged to note the particular qualities of the environment, and become aware of how the place was present, what sort of place it was, what it was like to be in this place. Once settled in this imaginal environment, an exploration of the sensate experience was undertaken; and another somatic anchor was established by intensifying the attentional focus on the place in the perceptual field where the experience was most intense. The participant was then directed into a brief period of sequentially sensing the somatic anchors creating a composite network of the two anchor points. Thereafter the participant was returned to their normal waking state.

The following post session instructions were provided to participants:

1) Practice sensing the "composite" of the two anchor points for a total of twenty minutes per day by re-embodying the sensory experience for brief periods of time repeatedly throughout the day; 
2) Sense the composite for 30 to 60 seconds prior to engaging the creative project. Once the brief sensing period is completed, simply engage the project in the usual way (without consciously trying to hold onto any mental/emotional/somatic state occasioned by the composite);

3) Sense the composite for 30-60 seconds prior to going to sleep at night and record any dreams that emerge. Bring the dreams to the next session.

\subsubsection{Session 2 - dreamwork}

Session 2 was generally scheduled one week after session one. Dreams that emerged during the intervening week were the focus of session 2 . When multiple dreams were available, the participant was encouraged to participate in selecting the dream that intuitively felt most relevant. This was often a dream that naturally drew attention by seeming most alien to waking consciousness.

The EI method of working with the selected dream was then employed. As with session 1 , the participant was guided in a brief sensing practice focused on body awareness and inward focus until they felt as if they could re-enter the atmosphere of the dream, as if it was being experienced in the present moment. Then, selected dream images were engaged. For the purposes of the study, three dream images were chosen and attention sequentially focused on each. When engaging the images, the particular focus was on experiencing the independent subjectivity of each image. Using focused attention on the qualities presented by the dream image, the dreamer was slowly encouraged to participate in its experience. This was generally accomplished by encouraging the dreamer to imaginally join in the posture, movements and countenance of the image until the dreamer felt as if they could participate in the independent experience of the image. EI refers to the experiential participation in the imaginal other as a "transit". Once established in the transit experience, the dreamer was guided in amplifying the experience by carefully paying attention to the emotional and sensate qualities that were present. A somatic anchor for each image was established as previously described. Subsequently the dreamer was guided in re-experiencing each of the three anchor points by sequentially attending to the somatic experiences in an effort to experience them simultaneously. The end result was the development of a "composite" consisting of a network of the three anchor points. Similar to the instructions provided after session 1 , participants were directed to:

1) Practice sensing the composite for a total of 20 minutes per day by returning to the embodied sensory experience for brief periods of time repeatedly throughout the day;

2) Sense the composite for 30 to 60 seconds prior to engaging the creative project. Once the brief sensing period is completed simply engage the project in the usual way.

Session 2 included an EEG recording taken while participants engaged their dreams in the EI session. The recordings allowed for an analysis of the percentage of time participants spent in compliance with the AM pattern while they participated in the session. The EEG was recorded using the Vilistus $M M$ 6, the latest version of the original $M M$ invented by Cade (Cade \& Coxhead, 1979). The MM is two channel EEG that monitors and records brainwave amplitudes in real time and performs frequency analysis. The $M M$ displays the results on 
horizontal barographs as a bilateral hemispheric display. The display panel has two columns of bar graphs which represent the left and right hemispheres ( $\mathrm{LH}$ and $\mathrm{RH}$ ). Each barograph represents one filter. The filters that analyze the brain signals are centered on the following frequencies: $0.7 \mathrm{~Hz}, 1.5 \mathrm{~Hz}, 3 \mathrm{~Hz}, 4.5 \mathrm{~Hz}, 6 \mathrm{~Hz}, 7.5 \mathrm{~Hz}, 9 \mathrm{~Hz}, 10.5 \mathrm{~Hz}, 12.5 \mathrm{~Hz}, 15 \mathrm{~Hz}, 19 \mathrm{~Hz}$, $24 \mathrm{~Hz}, 30 \mathrm{~Hz}, 38 \mathrm{~Hz}, 49 \mathrm{~Hz}$ and $59 \mathrm{~Hz}$. The electrodes were placed using the international 10-20 system (Jasper, 1958) in the same five positions used by Cade, for his original $M M$ readings: The ground wire on the forehead, O1/O2 for the passive electrodes, and T5/T6 for the active electrodes. This electrode placement allows for recording of activity in the $\mathrm{LH}$ and $\mathrm{RH}$ of the brain.

\subsubsection{Data collection and analysis}

Self-reported narratives of participants' memories, of feeling blocked or stalled with their projects, were recorded during the first (induction) session. Subsequently, narrative descriptions of the impact of the two session EI experience on participants' creative projects were collected one week after completion of the second (dream-work) session.

Subjective ratings of EI session impacts were also quantified by participants one week after each of the sessions, using a five point Likert-type scale ranging from "no help" to "very much help". Impacts were rated in response to the following four questions:

1) Rate the impact of practicing the composite on initiating engagement with your project - did it seem to help you start your work?;

2) Rate the impact of practicing the composite on sustaining engagement with your project - did it seem easier to maintain focus and engagement?;

3) Rate the extent to which the composite seemed to assist you in being "in the flow" with your project;

4) Rate the extent to which the composite seemed to support the generation of new ideas as you worked on your project.

Additionally, self-report data was collected specific to any adverse cognitive, emotional or somatic effects the EI process may have evoked over the two weeks of the study. The data was collected using a five point Likert-type scale ranging from "none at all" to "a lot".

EEG data was collected during the second (dreamwork) session using the $M M$, and the EEG data was analyzed using the $M M$ analytic software. The analysis focused on establishing the presence of the classic AM pattern (Cade \& Coxhead, 1979). Compliance with the classic AM pattern requires the presence of a specific proportional amplitude relationship between the four frequency bands (beta, alpha, theta, delta) used in Cade's (Cade \& Coxhead, 1979) original formulations. On the $M M$, compliance patterns for AM are set with the following relative amplitude relationships between frequency bands (S. Clark, personal communication November 11, 2016):

1) Beta (19 Hz peak frequency): 0.86 ;

2) Alpha (10.5 Hz peak frequency): 2.0 ;

3) Theta (6 Hz peak frequency): 1.2 ;

4) Delta (1.5 Hz peak frequency): 1.6. 
For study purposes the "demand" for compliance on the $M M$ was set at "level 5" using the $M M$ analytic software. Level 5 is a demand level typically used when experienced meditators employ the $M M$ for AM training purposes. Demand at this level indicates that compliance would be affirmed if the AM proportional relationships were present fifty percent of the recorded time, in either or both hemispheres of the brain. Sessions lasted approximately sixty minutes and compliance with the AM pattern was determined every one second throughout the session.

AM compliance scores for the seven participants were combined into median scores for each of the separate segments of the EI process (body awareness/sensing, telling dream, transits 1, 2 and 3, composite). These combined scores were then merged into a combined score reflecting the entire EI process ("Combined EI process score"). This score was then compared to baseline ("Talk-baseline"). Also, median scores for AM after the EI session was completed ("Return to talk") were compared to median scores when participants reengaged the composite ("Re-engage composite"). The data was merged in this manner in an effort to reflect the impact of the total EI process, as compared to baseline conditions. Descriptive (frequency, median, range) and nonparametric comparative statistics (Wilcoxon signed-rank test for matched pairs) were calculated. Separate scores for each segment of the EI process are presented (see Figure 2), as five statistics specific to AM compliance for the seven participants (minimum score, first quartile, median, third quartile and maximum), and also outliers.

\subsection{Results}

\subsubsection{Participant descriptions}

Seven participants took part in the study. Participant descriptions are provided in Table 1 for gender, age, occupation and creative endeavor.

\subsubsection{Participant narratives and subjective ratings}

Participants' self-reported memories of an exemplary moment of feeling blocked or stalled, when engaging their creative project prior to the EI process, are summarized in Table 2. Narrative descriptions of the self-reported impact of EI on participant creative projects were collected one week after the second session and are summarized in Table 3. All participants reported that the EI process had a positive impact on their CPs, one week after the second session.

The impact of EI on the CP was quantified using ratings done on a five point Likert-type scale from "No help" (numeric value 1) to "Very much help" (numeric value 5). The numeric results of the responses to the four questions were combined and a mean score calculated. The mean scores were rounded to the nearest whole number, and are displayed in Figure 1. As demonstrated in Figure 1, participant responses suggested that the second (dreamwork) session was more consistently impactful than the first (induction) session, but the small sample size precluded statistical verification of this tendency. 
Table 2. Participants' memories - employed in session 1 (induction) (source: created by author)

\begin{tabular}{|c|l|}
\hline Participant & \multicolumn{1}{|c|}{ Memory of "Block" } \\
\hline 1 & Teaching a student: A feeling of being disconnected, arms feel heavy, heart feels sad. \\
\hline 2 & At my computer: Wrote a few sentences, didn't work, feel stuck, anxiety in my left chest. \\
\hline 3 & $\begin{array}{l}\text { Coffee shop: Stressful time with my girlfriend, frustrated with not being able to } \\
\text { write, a familiar infuriated feeling, pain in my mid-forehead. }\end{array}$ \\
\hline 4 & Sitting at my desk: A feeling of being dumb and unable to express myself. \\
\hline 5 & $\begin{array}{l}\text { Sitting at my computer: I know what I want to say but can only type meaningless } \\
\text { words, it feels like pieces of stone in my brain. }\end{array}$ \\
\hline 6 & $\begin{array}{l}\text { Sitting at my desk: Feeling anxious and constricted, hard to communicate with } \\
\text { others about the organization. }\end{array}$ \\
\hline 7 & $\begin{array}{l}\text { Sitting at my desk: Overwhelmed and stuck with nowhere to go with the project, } \\
\text { feels like spinning in my head. }\end{array}$ \\
\hline
\end{tabular}

Table 3. Participants' descriptions of embodied imagination impact on creative process (after session 2) (source: created by author)

\begin{tabular}{|c|l|}
\hline Participant & \\
\hline 1 & $\begin{array}{l}\text { It was like a moment of amazement, a release from stuck linear patterns, and a } \\
\text { connected state where inspiration flows. }\end{array}$ \\
\hline 2 & It helped! The work is getting done. \\
\hline 3 & $\begin{array}{l}\text { It did help. I made headway. I felt an increase in creativity in general, like I started } \\
\text { five new songs one day. }\end{array}$ \\
\hline 4 & $\begin{array}{l}\text { The creative energy went "woo hoo". I was attracted to the writing. I was in the flow } \\
\text { creatively and with the writing. }\end{array}$ \\
\hline 5 & $\begin{array}{l}\text { It was extremely helpful and surprisingly too. The induction may have had a bigger } \\
\text { impact than the dream. }\end{array}$ \\
\hline 6 & $\begin{array}{l}\text { I felt a sense of ordering in the midst of lack of structure. The composite helped me } \\
\text { stay with the process. }\end{array}$ \\
\hline 7 & $\begin{array}{l}\text { It's like a backdoor into the process, like going into my subconscious, like piecing a } \\
\text { puzzle together and things manifest. Am I making this up? }\end{array}$ \\
\hline
\end{tabular}

5

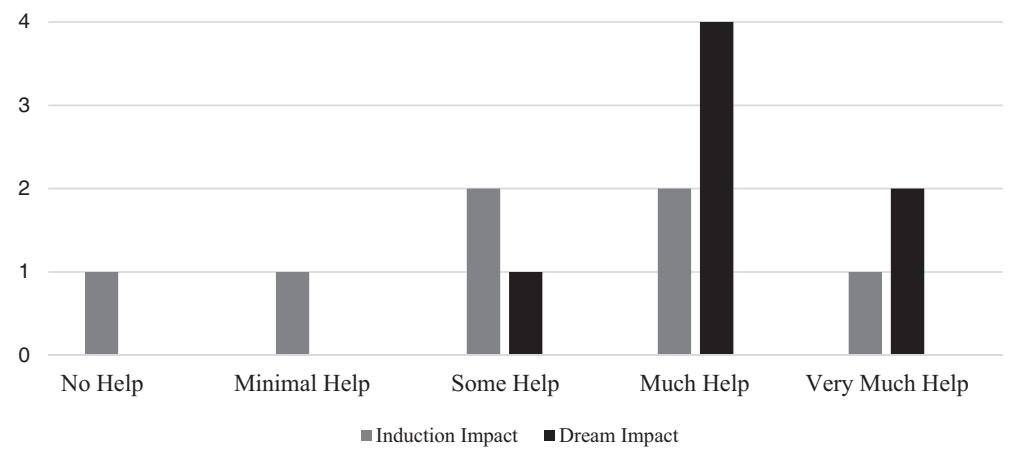

Figure 1. Number of participants by subject impact

(source: created by author) 
One week after the completion of the second EI session, participants were asked to report the presence of any adverse somatic, emotional or cognitive side effects of the EI process on a five point Likert-type scale from "None at all" to "A lot". Reports were available from six of the seven participants. An administrative error led to the data not being collected from the seventh participant. None of the reporting participants reported any adverse effects (all participants responded "None at all”).

\section{Neurophysiological data: awakened mind}

Figure 2 displays the combined data for seven participants and shows five statistics (minimum, first quartile, median, third quartile, and maximum) expressed as a percentage of time compliance with the AM pattern was detected by the $M M$ analytic software, for each segments of the EI session.

The results of paired sample Wilcoxon signed-rank test are provided in Table 4. Statistically significant differences were found between median baseline scores ("Talk-baseline") and the dreamwork session scores ("Combined EI Process Score") $(Z=-2.37, p=0.018)$. Statistically significant differences were also found between median scores when comparing "Return to baseline" with "Re-engage composite" $(Z=-2.37, p=0.018)$.

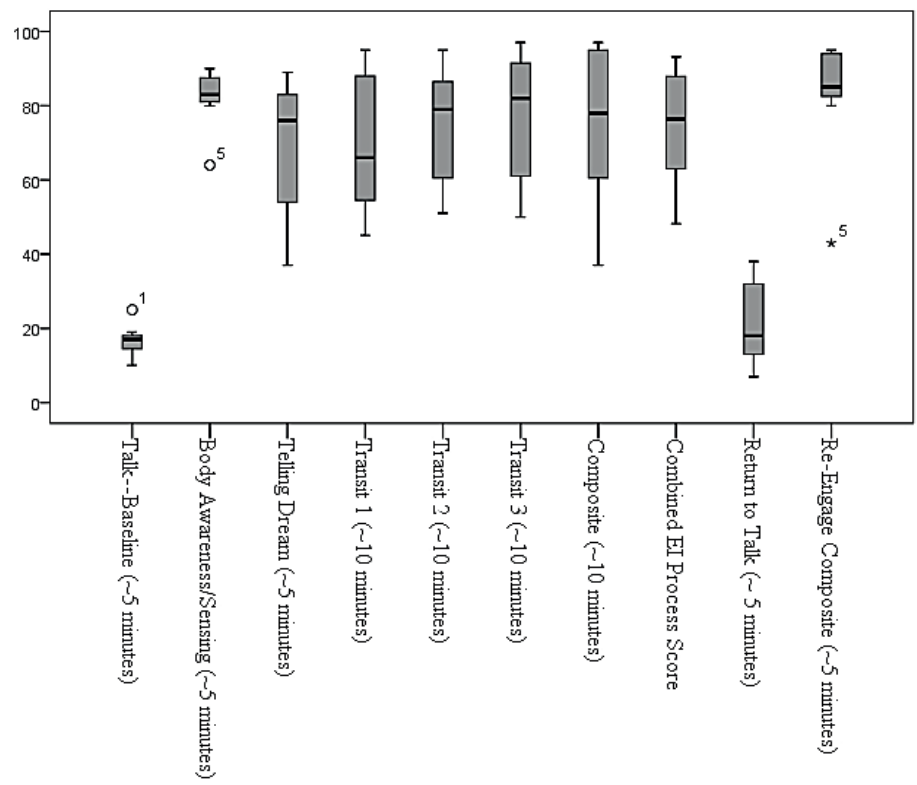

The boxplots combine data for seven participants and show five statistics (minimum, first quartile, median, third quartile, and maximum) and outliers

Figure 2. Awakened mind-percent compliance at demand level 5 - combined data (source: created by author) 
Table 4. Wilcoxon signed-rank test for matched pairs of awakened mind (source: created by author)

\begin{tabular}{|l|c|c|c|}
\hline \multicolumn{1}{|c|}{ Comparison } & Median & Z & p \\
\hline Phase 1 & & -2.37 & 0.018 \\
\hline Talk-baseline & 17.0 & & \\
\hline Comb. embodied imagination Process score & 76.3 & & \\
\hline Phase 2 & & -2.37 & 0.018 \\
\hline Return to talk & 18.0 & & \\
\hline Re-engage composite & 85.0 & & \\
\hline
\end{tabular}

Participant 5's compliance scores were outliers for "Body Awareness/Sensing" and "ReEngage Composite". However, as delineated in Table 5, Participant 5's individual scores, on each segment of the EI process, followed a similar pattern as all other participants.

Table 5. Subject 5 - percent compliance with awakened mind at demand level 5 (source: created by author)

\begin{tabular}{|l|c|c|c|c|c|c|c|c|c|}
\hline & Talking & Sensing & $\begin{array}{c}\text { Telling } \\
\text { dream }\end{array}$ & T1 & T2 & T3 & Composite & Talking & $\begin{array}{c}\text { Re-engage } \\
\text { composite }\end{array}$ \\
\hline $\begin{array}{l}\text { Awakened } \\
\text { Mind }\end{array}$ & 14 & 64 & 37 & 49 & 52 & 50 & 37 & 29 & 43 \\
\hline
\end{tabular}

In summary the results demonstrate that participants subjectively rated increased progress with their creative projects, after the two step EI intervention. Also, during the EI dreamwork session, participants' EEGs indicated entry into the AM pattern at significantly greater rates than baseline. Similarly, participants' EEGs indicated re-entry into the AM pattern at significantly greater rates when re-engaging the composite.

\section{Discussion}

This PS provides preliminary evidence for the effectiveness of EI as a support for the CP. A brief two-step EI intervention, beginning with a memory of a creative block, and followed by work with an emergent dream, was found to increase creativity, as judged by the first person accounts of study participants. Also, during the EI process participants were found to enter a neurophysiological state designated the AM. The AM state is distinguished by a specific proportional relationship between beta, alpha, theta and delta waves on the EEG and is thought to represent a more creative form of waking awareness (Cade \& Coxhead, 1979; Wise, 1995, 2002). Not only were participants able to enter AM while engaged in the EI process but they were able to re-enter AM when re-engaging the composite (a somatically anchored network of experiences generated in the EI session) after the EI session. This is important, as re-engaging the composite between sessions, was a foundational component of the EI intervention used in this study.

Fundamental to EI and AM is an experience of dream-like consciousness being present concurrent with wake-like consciousness. Importantly, while the EI process used in this study 
increased creativity, participants did not report any adverse cognitive, emotional or somatic effects. The lack of untoward effects is relevant as co-mingling the ordinarily separate states of waking, dreaming and sleeping, has been associated with both creativity and psychopathology (Llewellyn, 2016, 2011). In this study the co-mingling of wake-like and dream-like states, using the EI process, resulted in enhanced creativity with no apparent adverse effects.

While the current study cannot provide clarity regarding the mechanisms by which EI might facilitate creative emergence, Bosnak relates the following theoretical account of his efforts to understand and conceptualize this phenomenon:

"Here complexity theory, as developed by the Santa Fe Institute in the 1980's and 1990 's, came to my aid. Complexity theory posits that on the border between order and chaos - on the verge of going out of control, but not entirely - the most creative processes would unfold in such disparate fields as biology, physics, mathematics, economics, and artificial intelligence" (2007, p. 15).

That is, the brain/mind can be understood as a complex, self-organizing systems with non-linear dynamics (A. A. Fingelkurts, A. A. Fingelkurts, \& Neves, 2013). EI operates at the intersection between the relative stability of waking awareness and the ephemeral milieu of dream and imagination. Both the induction of the AM state and the engagement with dream images in EI support an interplay between conventional waking awareness and the fluid reality of dream and imagination. Creative emergence is then theoretically facilitated as conventional waking consciousness is infused with, and impacted by, dream-like consciousness. The containment provided by the EI method and the focused awareness applied to the experience both serve to modulate the entropic tendency toward random disorganization. Together these factors support the natural propensity of a complex systems such as the brain/mind to move towards creative self-organization. The increase in creative inspiration experienced by participants in this study, is then theorized to be an expression of this selforganizing tendency, which results in creative projects moving forward with renewed vigor.

\section{Limitations and future directions}

This PS is observational and is without a comparison group, limiting confidence in the findings. Also the sample size used was small. Hence it is not possible to be certain that the EI intervention was responsible for the creative emergence reported by the study participants. Future controlled studies with a larger sample size would serve to increase confidence in a causal relationship between the EI method and increased creativity. Also, the impact of the EI intervention was assessed one week after the second session in this study. While a positive impact on creativity was demonstrated, it is less likely that the brief EI intervention used would have an enduring impact on participants' creativity. Additional studies with a longitudinal focus would be required to further explore the issue of transient versus more enduring impacts of EI on creative potentiality.

The EEG data in this study was collected with the Vilistus MM 6, a 2-channel EEG, with electrodes placed occipitally and temporally, as in Cade's (Cade \& Coxhead, 1979) original experiments. While the small number of cortical sites monitored is a limitation of the study (in contrast to the 19 channel EEG typically used clinically or the 256 channel EEG some- 
times used in research), the $M M$ has some unique features. The $M M$ takes a broad EEG frequency spectrum and monitors the dynamic interaction between frequency band amplitudes in real time. Cade's (Cade \& Coxhead, 1979) AM theories are specific about the importance of the interaction between frequency bands, as they relate to states of consciousness. Cade's AM formulation is novel and worthy of additional inquiry with a broader range of neuromonitoring and neuroimaging tools, allowing for more detailed exploration of AM in relation to anatomical sites, functional neural networks and concurrent subjective experience.

Lastly, Cade's AM theories did not include consideration of gamma waves $(25-200 \mathrm{~Hz})$. Increased gamma has been identified at the moment of creative insight (Jung-Beeman et al., 2004), and also in novel states of consciousness such as advanced meditation (Lutz, Greischar, Rawlings, Ricard, \& Davidson, 2004; Ferrarelli et al., 2013), mystical states (Beauregard \& Paquette, 2008) and lucid dreaming (Voss, Holzmann, Tuin, \& Hobson, 2009). An exploration of the relationship between AM and gamma frequencies, as they relate to non-ordinary states consciousness, EI and creativity, would be a valuable focus for further research.

\section{Conclusions}

The findings of this PS suggest that EI is an effective support for the CP. The EI process facilitates a dynamic interplay between waking consciousness and dream consciousness theoretically evoking a more creative form of waking awareness, and an increase in creative productivity. Follow up studies are needed to increase confidence in the study findings.

\section{Acknowledgements}

The author thanks Roger Knudson and Sheila Ronsen for their support, review and critique of the manuscript, Robert Bosnak for assistance with design of the EI intervention, Deborah Goebert for statistical support, and Judith Pennington and Stephen Clark for technical support with the MM EEG and analytic software.

\section{References}

Andrews-Hanna, J. R. (2012). The brain's default network and its adaptive role in internal mentation. Neuroscientist, 18(3), 251-270. https://doi.org/10.1177/1073858411403316

Barrett, D. (1993). The "Committee of Sleep": a study of dream incubation for problem solving. Dreaming, 3(2), 115-122. https://doi.org/10.1037/h0094375

Barrett, D. (2001). The committee of sleep: how artists, scientists, and athletes use dreams for creative problem-solving - and how you can too. Norwalk, CT: Crown/Random House.

Bass, M., Nevicka, B., \& Velden, Ten F. S. (2014). Specific mindfulness skills differentially predict creative performance. Personality and Social Psychology Bulletin, 40(9), 1092-1106. https://doi.org/10.1177/0146167214535813

Beaty, R. E., Benedek, M., Wilkins, R. W., Jauk, E., Fink, A., Silvia, P. J., Hodges, D. A., Koschutnig, K., P. Neubauer, A. C. 2014. Creativity and the default network: a functional connectivity analysis of the creative brain at rest. Neuropsychologia, 64, 92-98. https://doi.org/10.1016/j.neuropsychologia.2014.09.019

Beauregard, M., \& Paquette, V. (2008). EEG activity in Carmelite nuns during a mystical experience. Neuroscience Letters, 444(1), 1-4. https://doi.org/10.1016/j.neulet.2008.08.028 
Bosnak, R. (2007). Embodiment: creative imagination in medicine, art and travel. New York, NY: Routledge. https://doi.org/10.4324/9780203961391

Bosnak, R., Busetto, P., \& Wolfe, E. (2015). Lautonomia di un personaggio: l'immaginazione incarnata nel processo creative. Revista di Psicologia Analitica. Nouva serie, 39(91), 53-86.

Buckner, R. L., Andrews-Hanna, J. R., \& Schacter, D. L. (2008). The brain's default network: anatomy, function, and relevance to disease. Annals of the New York Academy of Sciences, 1124(1), 1-38. https://doi.org/10.1196/annals.1440.011

Bulkeley, K. (2010). Dreaming as inspiration: evidence from religion, philosophy, literature, and film. International Review of Neurobiology, 92, 31-46. https://doi.org/10.1016/S0074-7742(10)92002-3

Cade, C. M., \& Coxhead, N. (1979). The awakened mind: biofeedback and the development of higher states of awareness. New York: Delacorte Press/Eleanor Friede.

Castle, Van de R. L. (1994). Our dreaming mind: a sweeping exploration of the role that dreams have played in politics, art, religion, and psychology, from ancient civilizations to the present day. New York: Ballantine Books.

Corbin, H. (1964). Mundus imaginalis, or the imaginary and the imaginal. Retrieved from http://www. imagomundi.com.br/espiritualidade/mundus_imaginalis.pdf

Domhoff, G. W., \& Fox, K. C. R. (2015). Dreaming and the default network: a review, synthesis, and counterintuitive research proposal. Consciousness and Cognition, 33, 342-353. https://doi. org/10.1016/j.concog.2015.01.019

Ellamil, M., Dobson, Ch., Beeman, M., \& Christoff, K. (2012). Evaluative and generative modes of thought during the creative process. NeuroImage, 59(2), 1783-1794. https://doi.org/10.1016/j.neuroimage.2011.08.008

Ferrarelli, F., Smith, R., Dentico, D., Riedner, B. A., Zennig, C., Benca, R. M., Lutz, A., Davidson, R. J., \& Tononi, G. (2013). Experienced mindfulness meditators exhibit higher parietal-occipital EEG gamma activity during NREM sleep. PLoS ONE, 8(8), 1-9. https://doi.org/10.1371/journal.pone.0073417

Fingelkurts, A. A., Fingelkurts, A. A., \& Neves C. F. H. (2013). Consciousness as a phenomenon in the operational architectonics of brain organization: criticality and self-organization considerations. Chaos, Solutions \& Fractals, 55, 13-31. https://doi.org/10.1016/j.chaos.2013.02.007

Fox, K. C. R., Nijeboer, S., Solomonova, E., Domhoff, G. W., \& Christoff, K. (2013). Dreaming as mind wandering: evidenced from functional neuroimaging and first-person content reports. Frontiers in Human Neuroscience, 7, 1-18. https://doi.org/10.3389/fnhum.2013.00412

Fox, M. D., Snyder, A. Z., Vincent, J. L., Corbetta, M., Essen, Van D. C., \& Raichle, M. E. (2005). The human brain is intrinsically organized into dynamic, anticorrelated functional networks. Proceedings of the National Academy of Sciences of the United States of America, 102(27), 9673-9678. https://doi.org/10.1073/pnas.0504136102

Gilhooly, K. J. (2016). Incubation and intuition in creative problem solving. Frontiers in Psychology, 7, 1-9. https://doi.org/10.3389/fpsyg.2016.01076

Hillman, J. (2004). Archetypal psychology: a brief account. Series: James Hillman Uniform Edition. Vol. 1. Dallas: Spring Publications, Inc.

Pace-Schott, E. F., Hobson, J. A., \& Stickgold, R. (2008). Sleep, dreaming, and wakefulness. In L. R. Squire, F. E. Bloom, S. du Lac, A. Ghosh, \& D. Berg (Eds.), Fundamental neuroscience (pp. 959-986). Burlington, MA: Academic Press.

Jasper, H. (1958). Report of the committee on methods of clinical examination in electroencephalography: 1957. Electroencephalography and Clinical Neurophysiology, 10(2), 370-375.

https://doi.org/10.1016/0013-4694(58)90053-1

Jung, C. G. (1974). Dreams. Princeton, NJ: Princeton University Press.

Jung-Beeman, M., Bowden, E. M., Haberman, J., Frymiare, J. L., Arambel-Liu, S., Greenblatt, R., Reber, P. J., \& Kounious, J. (2004). Neural activity when people solve problems with insight. PLoS Biology, 2(4), 0500-0510. https://doi.org/10.1371/journal.pbio.0020097 
Kokoszka, A., \& Wallace, B. (2011). Sleep, dreams, and other biological cycles as altered states of consciousness. In E. Cardena \& M. Winkelman (Eds.), Altering Consciousness: Multidisciplinary Perspectives. Vol. 2: Biological and Psychological Perspectives. Santa Barbara, CA: Praeger.

Kounios, J., \& Beeman, M. (2009). The Aha! moment: the cognitive neuroscience of insight. Current Directions in Psychological Science, 18(4), 210-216. https://doi.org/10.1111/j.1467-8721.2009.01638.x

Kounios, J., \& Beeman, M. (2015). The Eureka factor: Aha moments, creative insight, and the brain. New York: Random House.

Llewellyn, S. (2016). Crossing the invisible line: de-differentiation of wake, sleep and dreaming may engender both creative insight and psychopathology. Consciousness and Cognition, 46, 127-147. https://doi.org/10.1016/j.concog.2016.09.018

Llewellyn, S. (2011). If waking and dreaming consciousness become de-differentiated, would schizophrenia result?. Consciousness and Cognition, 20(4), 1059-1083. https://doi.org/10.1016/j.concog.2011.03.022

Lutz, A., Greischar, L. L., Rawlings, N. B., Ricard, M., \& Davidson, R. J. (2004). Long-term meditators selfinduce high amplitude gamma synchrony during mental practice. Proceedings of the National Academy of Sciences of the United States of America, 101(46), 16369-16373. https://doi.org/10.1073/pnas.0407401101

Marzetti, L., Lanzo, Di C., Zappasodi, F., Chella, F., Raffone, A., \& Pizzella, V. (2014). Magnetoencephalographic Alpha band connectivity reveals differential default mode network interactions during focused attention and open monitoring meditation. Frontiers in Human Neuroscience, 8, 1-11. https://doi.org/10.3389/fnhum.2014.00832

Mavromatis, A. (2010). Hypnogogia: the unique state of consciousness between wakefulness and sleep. London: Routledge.

Mok, L. W. (2014). The interplay between spontaneous and controlled processing in creative cognition. Frontiers in Human Neuroscience, 8, 1-5. https://doi.org/10.3389/fnhum.2014.00663

Nir, Y., \& Tononi, G. (2010). Dreaming and the brain: from phenomenology to neurophysiology. Trends in Cognitive Sciences, 14(2), 88-100. https://doi.org/10.1016/j.tics.2009.12.001

Nishida, M., Hirai, N., Miwakeichi, F., Maehara, T., Kawai, K., Shimizu, H., \& Uchida, S. (2007). Corrigendum to "Theta oscillation in the human anterior cingulate cortex during all-night sleep: an electrocorticographic study". Neuroscience Research, 58(2), 215-217. https://doi.org/10.1016/j.neures.2007.03.007

Nishida, M., Pearsall, J., Buckner, R. L., \& Walker, M. P. (2009). REM sleep, Prefrontal Theta, and the consolidation of human emotional memory. Cerebral Cortex, 19(5), 1158-1166. https://doi.org/10.1093/cercor/bhn155

Pace-Schott, E. F. (2009). Sleep architecture. In R. Stickgold \& M. P. Walker (Eds.), The neuroscience of sleep (pp. 11-17). London: Academic Press. https://doi.org/10.1016/B978-0-12-375073-0.50006-3

Raichle, M. E., Macleod, A. M., Snyder, A. Z., Powers, W. J., Gusnard, D. A., \& Shulman, G. L. (2001). A default mode of brain function. Proceedings of the National Academy of Sciences of the United States of America, 98(2), 676-682. https://doi.org/10.1073/pnas.98.2.676

Ritter, S. M., Baaren, van R. B., \& Dijksterhuis, A. (2012). Creativity: the role of unconscious processes in idea generation and idea selection. Thinking Skills and Creativity, 7(1), 21-27. https://doi.org/10.1016/j.tsc.2011.12.002

Ritter, S. M., \& Dijksterhuis, A. (2014). Creativity - the unconscious foundations of the incubation period. Frontiers in Human Neuroscience, 8, 1-10. https://doi.org/10.3389/fnhum.2014.00215

Runco, M. A., \& Jaeger, G. J. (2012). The standard definition of creativity. Creativity Research Journal, 24(1), 92-96. https://doi.org/10.1080/10400419.2012.650092

Sadler-Smith, E. (2015). Wallas' four-stage model of the creative process: more than meets the eye? Creativity Research Journal, 27(4), 342-352. https://doi.org/10.1080/10400419.2015.1087277

Schredl, M., \& Erlacher, D. (2007). Self-reported effects of dreams on waking-life creativity: an empirical study. The Journal of Psychology: Interdisciplinary and Applied, 141(1), 35-46.

https://doi.org/10.3200/JRLP.141.1.35-46 
Sio, U. N., \& Ormerod, Th. C. (2009). Does incubation enhance problem solving? A meta-analytic review. Psychological Bulletin, 135(1), 94-120. https://doi.org/10.1037/a0014212

Smith, S. M., \& Dodds, R. A. (1999). Incubation. In M. A. Runco \& S. R. Pritzker (Eds.-in-Chief), Encyclopedia of Creativity (pp. 39-44). Vol. 2. San Diego, CA: Academic Press.

Sonenberg, J. (2003). Dreamwork for actors. New York: Routledge.

Takahara, M., Kanayama, S., Nittono, H., \& Hori, T. (2006). REM sleep EEG pattern: examination by a new EEG scoring system for REM sleep period. Sleep and Biological Rhythms, 4(2), 105-110. https://doi.org/10.1111/j.1479-8425.2006.00201.x

Vincent, J. L., Kahn, I., Snyder, A. Z., Raichle, M. E., \& Buckner, R. L. (2008). Evidence for a frontoparietal control system revealed by intrinsic functional connectivity. Journal of Neurophysiology, 100(6), 3328-3342. https://doi.org/10.1152/jn.90355.2008

Voss, U., Holzmann, R., Tuin, I., \& Hobson, A. J. (2009). Lucid dreaming: a state of consciousness with features of both waking and non-lucid dreaming. Sleep, 32(9), 1191-1200. https://doi.org/10.1093/sleep/32.9.1191

Wallas, G. (1926). The art of thought. New York, NY: Harcourt, Brace and Company.

White, G. L., \& Taytroe, L. (2003). Personal problem-solving using dream incubation: dreaming, relaxation, or waking cognition? Dreaming, 13(4), 193-209. https://doi.org/10.1023/B:DREM.0000003143.00133.1c

Wise A. (2002). Awakening the mind: a guide to mastering the power of your brain waves. New York, NY: Penguin Putnam Inc.

Wise, A. (1995). The high performance mind: mastering brainwaves for insight, healing, and creativity. New York, NY: Penguin Putnam Inc.

\title{
SAPNAI, İKŪNYTA VAIZDUOTĖ IR KŪRYBINIS PROTAS: BANDOMASIS TYRIMAS
}

\author{
Richard R. SZUSTER
}

\section{Santrauka}

Šis bandomasis tyrimas - tai pirmosios pastangos išnagrinèti, kaip kūrybos procese pasitelkiama ịkūnyta vaizduotè. İkūnyta vaizduote - tai besiformuojantis metodas dirbti su sapnais ir vaizduote, kuri ịveiklina du fundamentalius procesus. Pirma, ¡̇kūnyta vaizduotė yra mišrios sąmoningumo būklès, apimančios patyrimus, panašius tiek ị būdravimą, tiek ị sapną, dalis. Antra, įkūnyta vaizduote yra tiesiogiai susijusi su sapnų vaizdiniais. Septyni dalyviai, kurie šiuo metu dalyvauja kūrybiniame projekte, vadovavo dviejų etapų ikūnytos vaizduotès procesui. Pirmosios sesijos metu buvo susitelkta ị jausmo, užsifiksavusio kūrybos procese, atsiminimą, o antrosios sesijos metu - i sapną, iškilusị laikotarpiu tarp dviejų sesijų. Buvo nustatyta, kad šis procesas - tai veiksminga paspirtis kūrybos procesui. Antrosios sesijos metu buvo pasinaudota elektroencefalografu, siekiant nustatyti, ar, vykstant ịkūnytos vaizduotès procesui, dalyviai tapo pabudusios sąmonès būklès. Keliama hipotezè, kad pabudusi sąmonè - tai kūrybiškesnè bundančio sąmoningumo, kuriam būdingas specifinio santykinio masto santykis tarp pasikartojančių smegenų bangų, forma. Buvo nustatyta, kad ịkūnytos vaizduotės sesijos metu dalyviai tapo pabudusio proto būklès ir gebejjo vèl panirti ị tokią būklę pasibaigus sesijai, iš naujo ịsijungdami ị „,sudètinị", somatiškai ịtvirtintą patyrimų tinklą, susikūrusị ịkūnytos vaizduotès sesijos metu.

Reikšminiai žodžiai: pabudusi sąmonè, kūrybiškumas, sapnai, įkūnyta vaizduotè. 